\title{
Undergraduate Pharmacy Student Perceptions of Tutorial in a Pharmacology of Antibiotics Course
}

\author{
Salfarina Ramli* \\ Department of Pharmaceutical Pharmacology and Chemistry, Faculty of Pharmacy, Universiti Teknologi MARA Selangor, Puncak Alam, \\ MALAYSIA.
}

\begin{abstract}
Introduction: This study aims at introducing a modified tutorial activity as part of learning and teaching activity in pharmacology of antibiotic course and collecting student perceptions about this tutorial. Methods: A total of 163 students were divided into smaller groups consist of 13-14 student per group. Tutorial questions were given a week before the face to face session with their tutor. Students answered 2 sets of tutorial questions and attended 2 face to face tutorial sessions before their midterm examination. An online survey was administered to collect student perceptions about the activity anonymously after the student received their midterm examination results. All students participated in the online survey. Results: Overall, students reported that the earlier given tutorial questions and interaction with tutor during face to face session enhance learning experiences and led to a better understanding of the fundamental concepts. This encouraged students to prepare for the midterm and final examination. Conclusion: The tutorials were activities that motivated students to acquire knowledge through a readiness of self-directing learning that improved student understanding of the course material.
\end{abstract}

Key words: Pharmacy education, Face-to-face tutorial, Active learning, Guided learning, Pedagogy.

\section{INTRODUCTION}

It is the aim of education to promote learning through experience and produce thinking individual. Apparently, knowledge is best obtained by answering questions regardless of the student learning style. Learning begins not with a didactic lecture but with a problem presented to the students. ${ }^{1}$ Ideally, through seeking for answer students will learn something new, as they are expected to have the inquiries of the course matters, discover something new by themselves and not through imitation taught by teachers, thus it means that the attainment of knowledge is original in nature. However, although the undergraduate students are young adults, they read primarily just so they are able to reproduce what they had read when they are questioned on it.
Understanding the learners is important for an educator in creating a satisfying and productive learning environment. Pharmacy undergraduates are learners that fit the pedagogical model and later the androgogical learning model as they are approaching their final year in the university (Table 1).

Tutorial is one of teaching strategies that aim to help students to learn a course by having a teaching and learning activity with the students in a smaller group. Problems or questions are given as assignment for student to complete, either by themselves or discussions with their peers. Standardized answer scheme or rubrics and trained tutor minimize the inconsistencies across the ratings from tutors. ${ }^{3}$ The questions work as the guidance that facilitates the learning but whether tutorial is an effective method of
Submission Date: 17-12-2018; Revision Date: 29-03-2019; Accepted Date: 06-08-2019

DOI: 10.5530/ijper.53.4.126 Correspondence: Dr. Salfarina Ramli, Department of Pharmaceutical Pharmacology and Chemistry, Faculty of Pharmacy, Universiti Teknologi MARA, Selangor-42300, Puncak Alam, MALAYSIA. Phone: +60332584832 E-mail: salfarina2892@ puncakalam.uitm.edu.my

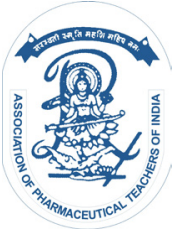

www.ijper.org 
Table 1: Pedagogical and andragogical assumptions about learners. ${ }^{2}$

\begin{tabular}{|c|c|c|}
\hline Aspect & Pedagogical Model & Andragogical Model \\
\hline Need to know. & $\begin{array}{c}\text { Learners need } \\
\text { to know what the } \\
\text { teacher tells them. }\end{array}$ & $\begin{array}{c}\text { Learner need to } \\
\text { know why something } \\
\text { is important prior to } \\
\text { learning it. }\end{array}$ \\
\hline $\begin{array}{c}\text { The learner's } \\
\text { self-concept. }\end{array}$ & $\begin{array}{c}\text { Learner has } \\
\text { a dependent } \\
\text { personality. }\end{array}$ & $\begin{array}{c}\text { Learners are } \\
\text { responsible for their } \\
\text { own decisions. }\end{array}$ \\
\hline $\begin{array}{c}\text { The role of } \\
\text { the learner's } \\
\text { experience. }\end{array}$ & $\begin{array}{c}\text { The learner's } \\
\text { experience is of little } \\
\text { worth. }\end{array}$ & $\begin{array}{c}\text { The learner's } \\
\text { experience has great } \\
\text { importance. }\end{array}$ \\
\hline $\begin{array}{c}\text { Readiness to } \\
\text { learn. }\end{array}$ & $\begin{array}{c}\text { Learners become } \\
\text { ready to learn what } \\
\text { the teacher requires. }\end{array}$ & $\begin{array}{c}\text { Learners become } \\
\text { ready to learn when } \\
\text { they see content as } \\
\text { relevant to their lives. }\end{array}$ \\
\hline $\begin{array}{c}\text { Orientation to } \\
\text { learning. }\end{array}$ & $\begin{array}{c}\text { Learners expect } \\
\text { course centered } \\
\text { content. }\end{array}$ & $\begin{array}{c}\text { Learners expect life } \\
\text { centered content. }\end{array}$ \\
\hline Motivation. & $\begin{array}{c}\text { Learners are } \\
\text { motivated by } \\
\text { external forces. }\end{array}$ & $\begin{array}{c}\text { Learners are motivated } \\
\text { by primarily by internal } \\
\text { forces. }\end{array}$ \\
\hline
\end{tabular}

teaching and learning is dependent on the way it is being conducted.

Some practices in tutorial include; student were giving out questions during the face to face tutorial session and was given a time to answer the questions just before the tutor starts a discussion, then students graded their tutorial answers by themselves. However, such practice in tutorial could result to ineffective learning session if the students come to the face to face tutorial session unprepared. Additionally, a study reported that students appear to be able to learn better when working independently and being given more responsibility and having regular feedback. ${ }^{4}$ Therefore, in this study, the way the tutorials were conducted was modified with an aim to encourage the student to prepare and to self-construct their knowledge in the Pharmacology of Antibiotics course. Student perception on this improved tutorial activity was collected using online survey. This study also explored the preparation of student for their midterm and final exam.

\section{MATERIALS AND METHODS}

\section{Participants}

The study population was all pharmacy students enrolled in the second year of the B. Pharm program. All of them took the Pharmacology of antibiotics course $(=163)$. In this course, students were introduced for the first time to the mechanism of action, pharmacokinetics, medicinal chemistry and adverse effect of groups of antibiotics. Students attended microbiology and pathology courses in the previous semester. Therefore, they are prepared with knowledge about micro-organism and infectious diseases. Students were made aware of the tutorials and midterm examination during the introduction of course plan at week $1^{\text {st }}$, which is the beginning of the semester and through online announcement in the university learning portal. Midterm examination was carried out at week $7^{\text {th }}$. The topics covered in the midterm examination include beta lactam, glycopeptide antibiotics and protein synthesis inhibitor agents.

\section{The tutorials}

A total of 163 students were divided into 12 small groups comprises of 13-14 students per group. 6 tutors were involved in this study. Each tutor was responsible for two tutorial groups, which were run on a separate day but on a same week. There were two tutorials before the midterm examination. Tutorial questions were prepared by lecturers that were assigned to teach the topics and were uploaded in the university learning portal on week $1^{\text {st }}$ and $4^{\text {th }}$ of academic timetable. Students were assigned to print and answer the tutorial questions before submitting it to their respective tutor within one week before the face-to-face session on week $3^{\text {rd }}$ and $6^{\text {th }}$, respectively. The format of tutorial questions included short essay and fill in the blanks questions, with the cognitive level of C1-C4 according to Bloom's Taxonomy, thus the tutorial was meant to only assessing student at acquiring knowledge, nothing on problem solving. Students were aware that tutorial marks were part of their continuous assessment marks. Total mark of each tutorial was 30 and 40 marks, respectively. Tutor graded the submitted tutorial and discussed the answer with student during the face to face session according to a standardized answer scheme. Midterm examination was also graded by tutor and the results were announced and discussed at week $8^{\text {th }}$. Midterm results were analyzed to observe student performance in the midterm (Figure 1). Results from midterm examination shows $7.36 \%$ of student $(n=12)$ failed the exam. Online survey was carried out to obtain student response about the tutorial.

\section{The online survey}

Students were asked to complete an anonymous, online survey after they have gotten their midterm results on week 8 . The questionnaire ( $n=10$ questions in total) was consisted of three sections measured using a five-point Likert scale (Strongly Agree, Agree, Neutral, disagree and Strongly Disagree). Section A ( $n=3$ questions) related to the way the tutorials were conducted, section $\mathrm{B}$ ( $n=5$ questions) focused on how the tutorial encourage 


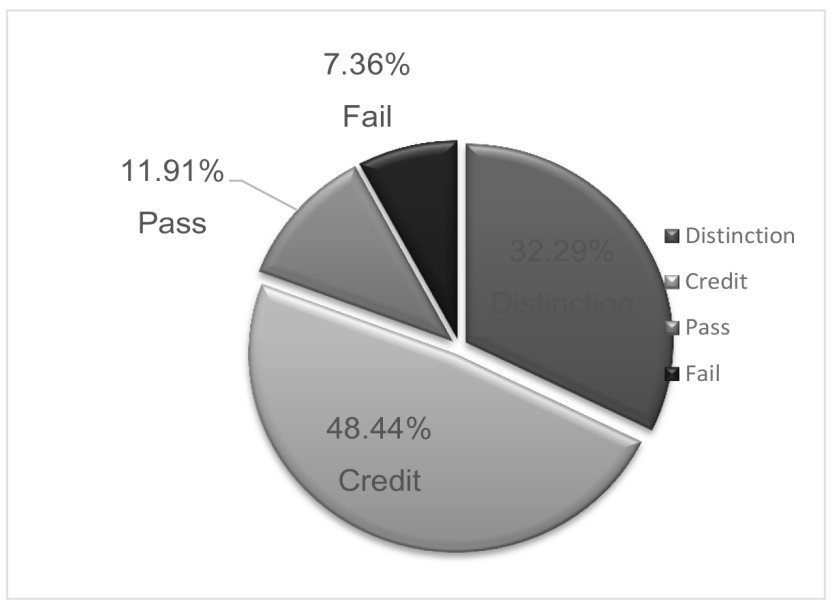

Figure 1: Midterm examination results.

the student to utilize face to face tutorial session as preparation of midterm examination. Finally, Section C ( $n=2$ questions) show student interest toward the course. The likert scale online survey instrument was available for student response for 5 days.

\section{Data analysis}

Statistical procedures were performed with excel 2010. Statistical significance was defined as $p<0.05$.

\section{RESULTS}

This study explored student's perception on the modified tutorials that was carried out as part of learning and teaching activity in the Pharmacology of Antibiotics course. Date stamps on questionnaire completion revealed that all participated student $(n=163)$ completed the survey within the allocated time.

From Table 2, results from section A shows $93.8 \%$ of student agreed that 1 week given was reasonable for them to complete the tutorial questions, this indicated students were able to allocate time for self-study. A $41.6 \%$ of students agreed for the tutorial question to be disseminated before the topic was taught in lecture, this demonstrated the student's readiness to learn new topics ahead of the schedule. Interestingly, $62 \%$ prefer to have face to face discussion with their tutors, thus shows that student valued having time with a tutor to help them through and develop an understanding of the course rather than independently relying on self-directed learning or online material. Only $16 \%$ of student agreed to have the tutorial answers uploaded online without face to face session. Results from section $\mathrm{B}$ indicates that majority of students did the tutorial seriously, looking forward for the face to face session, had confidence to discuss with their tutor and were encouraged to make preparations for midterm and final examinations. This could mean that the students were motivated by the tutorial activities, they were driven to work harder and prepared to come to the face to face session. It could also due to a realization that there are responsibilities that must be addressed as tutorial marks were part of their continuous assessment marks. However, only $31.3 \%$ of the students were satisfied with their midterm examinations results. Results from section C, shows majority of students agreed that pharmacology of antibiotics is an interesting subject whereas 29.4\% students agreed that learning foreign language is easier than memorizing antibiotic names. Next, correlation and regression analysis were carried out to find the relationship among variables.

From the correlation analysis (Table 3), the value of $r$ in the range $0.3-0.7$ was considered to indicate a moderate correlation, with lower values indicating a weak correlation and higher values a strong correlation. Although the variables are moderately correlated, regression analysis confirmed that by doing the tutorial, students have confidence to ask the lecturer/tutor for the topics they are not sure of $(p<0.05)$ and tutorial have been making students want to prepare for examinations $(p<0.05)$.

\section{DISCUSSION}

Tutorial is one of teaching method that has been practiced by educators to encourage students constructing their knowledge. Knowledge is built through tutorial as it facilitates communication and material exchange between tutors and students. In this study, tutorial questions were given earlier before the face to face session with aims at allowing the students to study at their own time with their own learning style and to have confidence at the knowledge they have constructed on their own. A research reported that students feel more confident that they are able to do and accomplish all academic demands in the form of assignments and exams, as they will develop a process of self-learning or self-regulated learning. ${ }^{5}$ However, major obstacles to learning are when students do not receive any feedback. ${ }^{6}$ Thus, in this study tutors graded the tutorial and discuss student performance during the face to face session. Students were expecting their marks and comments from their tutor in every face to face session. From the results, it was observed that student are comfortable at learning when they know what are expected from them, mainly when they find a way to match the learning environment with their own learning preferences. ${ }^{7}$

Preparation to receive knowledge is also important which are depicted in this study. There was a significant correlation between average grade and the careful preparation for learning. ${ }^{8}$ As observed in this study, 
Table 2: Student perception of tutorial in a pharmacology of antibiotic course.

\begin{tabular}{|c|c|c|c|}
\hline Question & $\begin{array}{c}\text { Disagree } \\
(\%)\end{array}$ & $\begin{array}{c}\text { Neutral } \\
(\%)\end{array}$ & $\begin{array}{c}\text { Agree } \\
(\%)\end{array}$ \\
\hline \multicolumn{4}{|l|}{ Section A: The way tutorial was conducted. } \\
\hline Time given to do the tutorial is reasonable. & 1.2 & 5.0 & 93.8 \\
\hline Tutorials are best uploaded before the topics are being taught in lecture. & 34.4 & 24.0 & 41.6 \\
\hline I prefer to have the answer to be uploaded in I-learn without face to face discussion with the tutor. & 62.0 & 22.0 & 16.0 \\
\hline \multicolumn{4}{|c|}{ Section B: Tutorial encourages the student to utilize face to face tutorial session as preparation of midterm examination. } \\
\hline I have been doing each tutorial seriously. & 1.2 & 3.7 & 95.1 \\
\hline I am looking forward to having face to face discussion with my tutor. & 0.6 & 6.1 & 93.3 \\
\hline I have confidence to ask the lecturer/tutor for the topics I am not sure of. & 1.8 & 9.8 & 88.4 \\
\hline Tutorials have been constantly making me want to prepare for midterm and final exam. & 3.7 & 13.5 & 82.8 \\
\hline I am satisfied with my midterm results. & 40.5 & 28.2 & 31.3 \\
\hline \multicolumn{4}{|l|}{ Section C: Student interest toward the course } \\
\hline I think Pharmacology of Antibiotics is an interesting course. & 0.6 & 10.4 & 89.0 \\
\hline I think learning foreign language is easier than memorizing antibiotic names. & 30.7 & 39.9 & 29.4 \\
\hline
\end{tabular}

Responses based on a five-point Likert scale ( $1=$ strongly agree; $2=$ agree; $3=$ neutral; $4=$ disagree; $5=$ strongly disagree). Agree $\%=$ Strongly Agree + Agree. Disagree $\%$ $=$ Disagree + Strongly Disagree.

\begin{tabular}{|c|c|c|}
\hline \multicolumn{3}{|l|}{$\begin{array}{l}\text { Dependent variable. } \\
\text { Students are satisfied with their midterm results. }\end{array}$} \\
\hline Independent variables: & $\begin{array}{l}\text { Correlation co-efficient, } \\
\qquad r \text { values }\end{array}$ & $\begin{array}{l}\text { Regression } \\
p \text { values }\end{array}$ \\
\hline Pharmacology of antibiotics is an interesting course. & 0.253 & 0.023 \\
\hline Tutorials have been constantly making students want to prepare for midterm and final exam. & 0.333 & 0.000 \\
\hline \multicolumn{3}{|c|}{$\begin{array}{l}\text { Dependent variable: } \\
\text { Tutorials have been constantly making students want to prepare for midterm and final exam. }\end{array}$} \\
\hline Independent variables: & $\begin{array}{l}\text { Correlation co-efficient, } \\
r \text { values }\end{array}$ & $\begin{array}{l}\text { Regression } \\
p \text { values }\end{array}$ \\
\hline Students have been doing each tutorial seriously & 0.276 & 0.139 \\
\hline Students are looking forward to having face to face discussion with tutor. & 0.337 & 0.043 \\
\hline $\begin{array}{l}\text { By doing the tutorial, students have confidence to ask the lecturer/tutor for the topics they are } \\
\text { not sure of. }\end{array}$ & 0.367 & 0.009 \\
\hline Pharmacology of antibiotics is an interesting course. & 0.274 & 0.094 \\
\hline
\end{tabular}

positive feedbacks were received from the students. Students performed well during their midterm exam (Figure 1) which was correlated with the preparation they made through tutorial (Table 2). The failure rate was less than $10 \%$ and only $31.3 \%$ students were satisfied with their midterm results, indicated there are rooms for improvement. Moreover, it takes time to change entrenched approaches to learning, certainly if they have been successful so far. ${ }^{9}$ Therefore, creating a satisfying and productive learning environment and ensure the knowledge has been transferred has always be the challenges to any educator. Thus, an educator has to take advantage of rote learners and their self-study behavior, to turn it to benefit the student.
The online survey was intended to collect feedbacks on the tutorial conducted. Participants in this study were second-year university pharmacy students with experiences of being in another mechanism of tutorial before in other subjects. Any comparison group was not established as the study was only focusing at collecting perception from the students about the way the tutorial was conducted can help them to construct their knowledge and prepare for their examinations.

\section{CONCLUSION}

Apparently, academic self-efficacy provides a strong foundation for students in constructing knowledge. Thus, in this study the student were demanded to answer 
or complete assignments in designated time before the face to face session, which was different from tutorial in other courses where questions were given during the face to face session. The student also got their feedback from their tutors on time. As a result, students become more prepared and able to develop self-regulated learning in their learning process. Results gathered from this survey will be used to design more learning activity for Pharmacology of antibiotics subject in the future. Next, technology and IT resources platform to generate teaching activity content will be incorporated as tools to enable student engagement and improving learning performance.

\section{ACKNOWLEDGEMENT}

The author would like to acknowledge all the tutors involved in this course that have given full cooperation and feedbacks in conducting the tutorials.

\section{CONFLICT OF INTEREST}

The author declare no conflict of interest.

\section{REFERENCES}

1. Boud D, Feletti GI. The Challenge of Problem-Based Learning. New York: St Martin's Press. 1991.

2. Knowles MS, Elwood FH, Swanson RA. The Adult Learner. Houston: Gulf Publishing. 1998.

3. Ingchatcharoen S, Tangdhanakanond K, Pasiphol S. Testing Measurement Invariance of Quality Rating Causal Models in Tutorial-Based Assessment. Procedia-Social and Behavioral Sciences. 2016;217:867-77.

4. Stark P. Teaching and learning in the clinical setting: a qualitative study of the perceptions of students and teachers. Medical Education. 2003;37(11):975-82.

5. DiBenedetto MK, Bembenutty $\mathrm{H}$. Within the pipeline: Self-regulated learning, self-efficacy and socialization among college students in science courses. Learning and Individual Differences. 2013;23:218-24.

6. Löfmark A, Wilblad F. Facilitating and obstructing factors for development of learning in clinical practice: A student prospective. Journal of Advanced Nursing. 2001;34(1):43-50.

7. Dolmans DHJM, Wolfhagen IHAP. The relationship between learning style and learning environment. Medical Education. 2004;38:800-4.

8. Marko U, Jereb E. Learning habits in higher education. Procedia - Social and Behavioral Sciences. 2014;116:350-5

9. Reid WA, Duvall E, Evans P. Can we influence medical students' approaches to learning?. Medical Teacher. 2005;27(5):401-7.

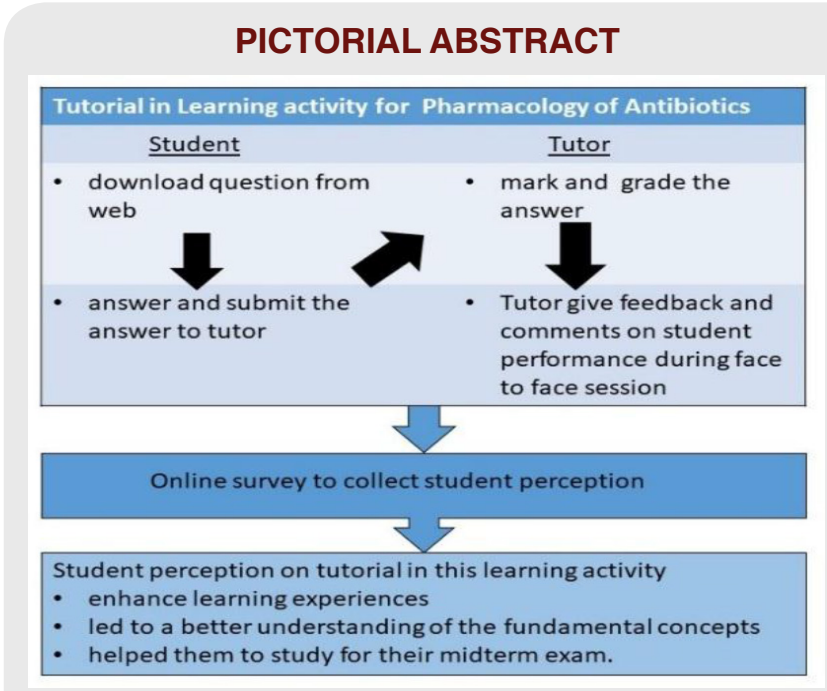

\section{SUMMARY}

- Face to face tutorial is one of learning activity for the Pharmacology of Antibiotic subject.

- In this activity, tutorial questions were uploaded online 2 weeks before the face to face tutorial session, students were asked to answer and submit their answer to be graded by their respective tutors a week before the face to face session. During the face to face session, tutor discussed the answer and commented on the student performance.

- Online survey was done to collect student perception on the tutorial in the learning activity.

- Positive feedbacks were received from the students and student agreed that tutorial in this learning activity helped them to study for their midterm exam.

\section{About Authors}

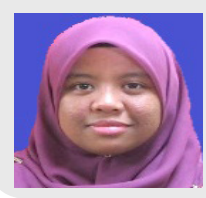

Dr Salfarina Ramli is currently a senior lecturer at the Faculty of Pharmacy, Universiti Teknologi MARA, Malaysia. She has interest in exploring teaching and learning method to effectively deliver the knowledge of Pharmacology.

Cite this article: Ramli S. Undergraduate Pharmacy Student Perceptions of Tutorial in a Pharmacology of Antibiotics Course. Indian J of Pharmaceutical Education and Research. 2019;53(4):649-53. 